\title{
A Model for Evaluating the Effectiveness of Educational Leadership: The Case of Greece
}

\author{
Andreas Dimopoulos \\ PO Box 3118, Fragma Thermis Post Code 57001, Thessaloniki Greece \\ Tel: 30-6936346617. E-mail: job1j@yahoo.gr; info@andreasdimopoulos.gr
}

\author{
Andreas Dimopoulos (Corresponding author) \\ $\mathrm{PhD}$ Candidate Department of Economics \\ Faculty of Social, Political, and Economics Sciences, Democritus University of Thrace \\ Panepistimioupoli, Komotini 69100, Greece \\ E-mail: secr@econ.duth.gr
}

Received: December 30, 2019

Accepted: January 25, 2020

Published: January 27, 2020

doi: 10.5296/ire.v8i1.16341

URL: https://doi.org/10.5296/ire.v8i11.16341

\begin{abstract}
Educational leadership has been studied in depth so far worldwide. However, to our knowledge, there is a broad scope for further research in terms of measuring educational leadership effectiveness. Many attempts throw the years were undergone in Greece in order to establish an evaluation process for educational leadership, many reactions raised, continuous changes have occurred and the issue remains timeless. This study aims to introduce a model of assessing the outcomes of educational leadership considering the most important stake holders that affect. These stake holders according to literature review in broader categories are the academic staff, school community, students, local society, and administrative personnel. Educational leader's effectiveness can be also assessed against their academic and operational duty results such as the implementation of national educational policy, administrative tasks and relative operational outcomes in budgeting, handling and overcoming managerial obstacles, meeting the legislation standards. The purpose of this research is to design a comprehensive, applicable and holistic evaluation model for assessing educational leadership based on the results on the above criteria. For this purpose an extensive relative literature review in educational leadership studies has been conducted in order to explore in depth the most significant recipients that educational
\end{abstract}


leadership influence and affect direct or indirect respectively. The core idea is that the most influenced recipients by educational leadership could be the most appropiriate evaluators for the results of it. Thus has been designed a model based on the most significant stake holders who affected by educational leaders, complimented with a questionnaire as evaluation tool, which is structured with particular questions for each broad category of stake holders. In this study a relative literature review, and a draft of a pilot evaluation model in assessing educational leadership presenting, while the ultimate target is in a following study the evaluation model to be implemented in real sample of participants in order to present the impact of educational leadership effectiveness with respect to subordinates of academic, managerial staff and students of an educational organization.

It is of a great importance to have an evaluation model for assessing the educational leadership effectiveness for all levels of education such as primary, secondary and higher education. Educational leaders affect many recipients such as students, faculty members, academics and community. Hence, a broader evaluation model should involve assessment criteria from all these stake holders due to the fact that educational leadership has a great direct or indirect influence in several micro and macroeconomic critical results, such as students achievements, learning outcomes, school climate, local society bonds, teachers behaviours, ethics, culture, civilization, and eventually national economy competiveness. A transparent evaluation model of school leaders could provide better understanding of the job left to be done for every educational leader, to recognise competences, to disclose weaknesses in order to work on them, to facilitate criteria for improvement, overcome obstacles and eventually to promote and improve educational efficiency.

Keywords: Educational leadership, Management, Evaluation model, Efficiency, Effectiveness

\section{Introduction}

\subsection{Statement of the Problem and Purpose of the Study}

Many attempts throw years have tried to evaluate and assess educational results and educational leadership effectiveness in Greece in all levels of education, particular in secondary and higher education. Several evaluation systems have organized, many reactions have been raised from academic community, many changes and failures have been realized and this situation continues. The main issue is if there could be a transparent, structured, fair and comprehensive way to measure the effectiveness of educational leadership. Thus, this study aims to create an appropriate assessment model of educational leadership effectiveness with objective, measurable and comparative criteria.

\subsection{Measuring the Effectiveness of Educational Leadership}

The concept of educational leadership and its effectiveness has been studied by scientists, academics, researchers and educational organizations over time from past years until today. Schools in order to check improvement process often examine the various leadership factors that play a substantial role in school effectiveness (Bruggencate, Luyten, Scheerens, \& Sleegers, 2012). Nevertheless, many remains to be done in Greece in assessing the educational leadership with an acceptable, objective and effective system, since despite the fact that significant efforts were made in the direction of this, however, did not result in a consistently and over-time acceptable evaluation model, resulting in many reactions being raised in 
particular with regard to the objectivity of the assessment methods and the criteria and thus the situation in such an important issue is fluid and often changeable. According to OECD Greece faces a major challenge in developing a culture of evaluation, as external evaluations have historically been distrusted, particularly by the teaching profession. Overall, there is no evaluation culture that takes results as the first criterion, or the basis for improvement strategies and distribution of responsibility (OECD, 2011, p. 45). This research was carried out to develop reflection, draw conclusions and finally formulate concrete proposals on the major issue of evaluating the effectiveness of educational leadership. Aim of this work is to focus on educational management and leadership correlating the effectiveness of leadership with measurable concrete criteria. More specifically, the effectiveness of the educational leadership and its evaluation is studied through the design of a standard evaluation model that takes into account the overall educational environment in all its dimensions and all potential recipients of leadership, defining specific efficacy criteria according to those recipients.

\subsection{Educational Leadership Effectiveness. A Term With Several Meanings}

Many times there are a variety of questions about leadership, for example if this is effective, or what are those criteria which determine leadership as effective, or in a more simplified version when a leader is effective or not. This study attempts to describe and 'delineate' the effectiveness of educational leadership with as clearly and adequately defined criteria as possible, in order to realize whether in education can be established objective criteria, how these can be set for assessing the effectiveness of educational leadership and which could be these individual criteria.

\section{Research Questions}

The general research hypothesis in this study is whether the effectiveness of the educational leadership is a result which could be measurable, adequately defined by relative qualitative or quantitative criteria and indicators. There are three main research questions on which we will try to provide a response through the provision of information that will emerge from the relevant literature review.

Research question 1: Who are the most appropriate raters of the educational administration and leadership? Can they be credible judges of the effectiveness of the educational administration and leadership?

Research question 2: Could the outcomes of the educational leadership be measurable with objective and clear criteria and which are these?

Research question 3: Can these criteria be credible, identified, set with qualitative and quantitative manner and evaluated objectively?

\subsection{Interest in Educational Leadership and Its Importance}

According to Leithwood and Riehl, (2003) interest in the field of educational leadership is constantly growing. In their view, this is because, on the one hand, the results of the educational process are systematically investigated; on the other hand, the leaders' influence on them is sought. Also, another reason for the intense interest in the field of education is that it has become demanding, there are constantly changes, resulting in new challenges emerging for leaders. The continuous flow of the results of various researches on leadership reignites the further involvement with it and its results. On the other hand, this results in increased criticism 
of school, educational leaders and findings which focus mainly on the 'deficiency' of education executives. According to the school leadership criticism, school leaders do not respond successfully to the guidance of their subordinates in terms of improving their teaching practices, they do not adequately exploit new technologies of it, do not revise-change their outdated administrative structures, do not provide the required services to all students, while finally not evaluated-accountable to a satisfactory extent according to the standards (Elmore, 2002). School leadership has become a priority in education policy agendas internationally. It plays a key role in improving school outcomes by influencing the motivations and capacities of teachers, as well as the school climate and environment. Effective school leadership is essential to improve the efficiency and equity of schooling (OECD, 2008). The role of educational leadership is considered very important for the promotion of the objectives of education and is one of the success factors of the schools (Edmonds, 1979). School leader is considered as one of the most influential factors in the development of the quality and character of a school (Cohen, McCabe, Michelli, \& Pickeral, 2009). Much of the previous research demonstrates that a principal's leadership style and skills impact a variety of teacher characteristics, from job satisfaction and efficacy, to levels of engagement and academic emphasis (Bird et al., 2009). It has very high impact on the improvement of the results of the school, having the potential to influence the motivation and performance of teachers by creating the appropriate climate and working environment (Pont, Nusche \& Moorman, 2008). Moreover, research has determined that principal leadership can have indirect but a significant, impact on student outcomes (Hallinger \& Heck, 1996; Marzano, Waters, \& McNulty, 2005; Robinson, Lloyd, \& Rows, 2008). The role of the leader in education is important, and the achievement of the objectives of the school unit, the creation of a vision in this, human potential and the further planning for its smooth operation, constitute an important mission. In addition, the different groups that are 'involved' or are recipients of any form of educational leadership such as teachers, pupils, parents, depend to a large extent on the decisions of the educational leader as we can see from the listing of the relevant bibliography.

\subsection{Evaluation of Educational Leadership Is a Matter of Relative but Concurrently Different Criteria of Effectiveness}

The phenomenon of leadership and its effects are inevitably interconnected with the necessity of achieving the results which in turn relate to a set of criteria and parameters. The exercise of educational leadership in an educational organization undoubtedly has multiple recipients and therefore its effectiveness must be studied in the light of the positive and/or negative effects to all of them. For example, pupils or students, teachers, administrative staff, the broader school community, educational policy outcomes, and the role of educational leader are crucial for all of them. A number of terms and concepts regarding educational effectiveness is undergone which frequently among other include "competent, accountability, development, improvement, evaluation, monitoring, reviewing, skilled, appropriateness, efficiency, quality and performance". All these terms make the concept of effectiveness a very broad meaning which makes sense to be connected with effort and accomplishments. For example the school head may identify school's effectiveness as the pupils' performance in the final examinations. On the other side, parents' could understand school's effectiveness in the way the pupils behave at home and their performance at national examinations. Society, possibly will 
observe the school's effectiveness in terms of the good moral manners' of the children. The Commonwealth Secretariat (1993) in its report describes the school effectiveness as general markers of internal performance, working, external concerns and staff output. More specifically describes the indicators of School Effectiveness as; "Purposeful leadership of the staff by the head, the involvement of the heads of department, the involvement of other teachers, structured lessons, intellectually challenging teaching, work-centered environment, maximum communication between teachers and pupils, efficient and accurate record keeping, parental and community involvement, positive climate, consistency among teachers, productive division of labour among teachers and good parental report". Nevertheless, it is never possible for a school which does not meet the expectations of society to be effective and successful (Drucker, 2012)

Many of the internationally accepted characteristics of school efficiency such as shared vision, mission and achievement of goals, are the product of an effective school leadership (Catano \& Stronge, 2006). The role of leadership in education is of catalytic importance for both the educational, school and the entire education system, and its effectiveness has been researched in relation to many different parameters, such as the school climate (Clifford et al., 2012; Allen, Grigsby, Peters, 2015) creating a sense of community in school (Beck \& Foster, 1999) and especially in relation to student outcomes, for example pupils' achievement (Henderson \& Mapp, 2002; Leithwood, 2002; Leithwood et al., 2004; OECD, 2013; Allen, Grigsby, Peters, 2015; Portin, et al., 2009) and teachers' expectations from the school leader (Thompson, 2017). Also other researchers looked at the effectiveness of leadership through self-assessment of the school unit (Macbeath, 2001), the correlation between evaluation and performance standards (Catano \& Stronge, 2006). The effective director possesses profound knowledge and experience in matters of administration and education and skills consisting of: a) the possession of strategies and methods and expertise in economics, construction and other matters $b$ ) in the perception of school as a living organism where the human factor is the key to balance and smooth operation as well as to the perception of the analytical program as a single material-Guide to educational act, c) to justice, understanding, leniency, appreciation, respect, collaboration, interest that contribute to the development of strong interpersonal relationships throughout the educational community (Stravakou, 2003). As they say Everard \& Morris, (1999) an effective director motivates students and educators and promotes the offer of equal learning opportunities. It has a stable administrative path, credibility, creates a climate of mutual respect, sets goals and conducts them, has flexibility, and takes initiatives. It shows confidence, creates positive, pleasant and creative climate, rationally manages the economics of the school, has the ability to guide students and enforce discipline, has the ability to influence the members of the school community and to lead them to positive results, collect information, collaborate with pupils, parents, teaching staff and other bodies.

Educational leadership and management processes, involve the arrangement and deployment of systems that ensure the implementation of educational policies, strategies, and action plans throughout a set of integrated practices in order to achieve specific educational targets. Process performance evaluation can only be optimised through a clear understanding of how different members of work fit into the whole organization system. It looks at how management gathers information to inform educational policy and strategy and involves the application of systems 
standards covering quality management systems (Lewis, Goodman \& Fandt, 1995). When process performance is well documented and analysed with a methodical way and compared with desirable results then generates facts on the basis of which the processes in question can be effectively handled and continuously improved. This functional information supports decisions at all management levels that in turn improve educational process performance further (Schoderbek, Cosier \& Aplin, 1988).

Hence, an evaluation of leader effectiveness based in transparent, objective, qualitative and quantitative criteria of achievement towards targets which have been set from all stake holders, such as academic and administrative staff, students, school community incorporating parents, could be more effective, objectively, accountable, metricate and broader accepted model.

\subsection{The Evaluation of Educational System in Greece. A Short Retrospection and Critical} Points

\subsubsection{School and Teacher Evaluation in Greece}

Until the 1980s, teacher evaluation was the job of school inspectors, and particularly during the 1967-74 military regime, inspection became associated with political control. In the early 1980s, and against this historical background, inspection was abolished, and the system of school advisors was introduced. According to the then law (L.1304 of 1982) school advisors were meant to undertake the evaluation of the educational system, but this was never implemented. A later law (Law 1566 of 1985), which also included references to educational evaluation, was not implemented during the 1980s. School advisors concentrated on providing pedagogical guidance and support to teachers. Several attempts in the 1990s to introduce educational evaluation in schools were met with fierce opposition by teachers' unions, teachers and even some students and parents; leading either to their formal invalidation, or to their non-implementation in practice. In the $2000 \mathrm{~s}$, the emphasis changed to more participative forms of educational evaluation focusing on the evaluation of educational work and self-evaluation of school units, rather than on individual teachers (Verdis, 2002) in (OECD, 2017, p.56). But according to Institute of Educational Policy the context remained one in which it was very hard to develop a culture of evaluation of them and assessment, as it was often seen as punitive and controlling means, jeopardising rather than reinforcing school and teacher autonomy (IEP, 2016).

\subsubsection{Self-Evaluation of Schools}

Starting from the 2013/14 school year and following a two-year pilot project, annual school self-evaluation became compulsory for all types of pre-primary, primary and secondary schools. The legislation (Circulars 30973/C1/05-03-2013, 190089/C1/10-12-2013, Ministerial Decision 30972/Г1/05-03-2014) states that at the beginning of each school year, every school is required to set its own educational goals and plan how to reach them (OECD, 2017, p. 56)

\subsubsection{Teacher Appraisal}

In parallel to school self-evaluation, a presidential decree (P.D. 152/2013) introduced a new teacher appraisal system to be implemented from 2014/15, linked to teachers' promotion and their tenure in posts of responsibility. According to this proposal, education staff would be subject to appraisal by their respective line managers on administrative matters, and their relevant education advisors on educational matters; so a teacher's appraisal would be carried 
out by the school head and relevant school advisor respectively, and that of a school head by the director of education and the relevant education advisor. The criteria, procedures and the form of the appraisal report were defined centrally. This teacher appraisal system was met with opposition by many teachers and by teachers' unions (in the context of education expenditure reductions due to the crisis). The teachers' unions then reacted against the newly established process of school self-evaluation, previously perceived in positive terms. All these educational evaluation processes, including school self-evaluation, were 'frozen' in 2015 (OECD, 2017, p. 56).

Over the past years, Greek governments have sought to address a number of issues through reforms in education effectiveness. However, where reforms have been introduced, they have often failed to make a real impact on the quality and efficiency of the system and to produce major global results as far as the performance of students and the achievement of learning objectives are concerned. New laws have often been enacted but not fully implemented. No reliable indicators are in place to provide information on the quality, efficiency and effectiveness of Greek education system. The system cannot rely on consistent tools for measuring the quality and effectiveness of the education system and the actual achievement of learning outcomes as there are neither external assessments of learning, based on standardized national assessments, nor external evaluations of schools and teaching (OECD, 2011, p. 14; OECD, 2017, p. 9, 53).

In Greece, according to OECD, (2011, p. 24) we have one of the most centralized education systems in Europe which functions ineffectively. One of the areas in which school directors have the least authority compared to other countries is in managing human resources. Strengthening school leadership is one of the most crucial challenges for education reform. Recently there have been modest moves towards decentralization, but while dropout rates are low in Greece, educational outcomes remain weak and the system is still highly centralized, school leaders in Greece currently have limited responsibilities and there is consensus that school self-evaluation should be reintroduced, together with some form of external accountability (OECD, 2017, p. 7). The agency's OECD (2011) research identified four areas of responsibility as key to increasing the effectiveness of the Director: 1) support, evaluation and development of teacher quality, 2) objectives, evaluation and accountability for educational leader itself, 3) strategic management of financial and human resources 4) cooperation with other schools. The above claim on the centralized education system is confirmed also by Papanaoum, (1995) which states that the director at the Greek School is mainly a recipient and executor of circulars and orders for all the main issues of responsibility. To this point it is worth mentioning, that to a large extent the 'deficiency' in school administration is sometimes not due to its leaders, but to the very system in which they are invited to lead (Mulford, 2003).

\subsubsection{Educational Leadership Evaluation}

At this point, however, it is appropriate to mention, how the effectiveness of the educational leadership in Greece is defined through the perspective by the framework of the relevant legislation. According to the Presidential Decree (P.D. 152/2013, FEK A 240/05-11-2013) the evaluation of the directors of school units is carried out in five categories of parameters including: the exercise of administrative and organisational work within the legislative 
framework, the exercise of the work of supervision and evaluation, the evaluation of the school climate and pedagogy of the school unit, planning, organize and preparation of teaching, conducting teaching and evaluating students, scientific and professional development. According to Saiti, (2008, p. 15) the evaluation of the educational project, is the continuous process of evaluating the quality of the education provided and the degree of implementation of its objectives and targets and the process of such control consists of four stages: a) Setting the performance standards (b) measuring performance (c) comparing the measurement to the standards and d) correcting deviations. Among other measures in order to enhance educational effectiveness OECD (2011, p. 43) recommended to Greece was to set goals and benchmarks for each region to improve the efficiency of the use of human resources and the rationalization of the school network, to establish performance agreements between the Ministry and each regional director for making step-by-step progress toward agreed goals, implementation of an evaluation and assessment framework, student assessment by aligning educational standards and student assessment, balancing external and teacher-based assessments of learning, integrating student formative assessment in the evaluation and assessment framework, teacher evaluation, school self evaluation with a view to designing and implementing a comprehensive system of assessment and evaluation based on results and outcomes.

\subsection{Considerations About Drawing the Assessment of Educational Leadership Effectiveness}

So far, it is understood that the effectiveness of educational leadership is a concept that can be identified with sufficient, objectively to a large extent, comparative and multiple criteria and parameters and certainly not a concept which is non-measurable, theoretical and subjective. In determining the criteria for the effectiveness of the educational administration, it is necessary to take into account as far as possible, objective and measurable criteria of all the addressees that it affects, in order process off assessing leadership to be as meritocratic, fair, measurable and thorough as possible. Also, in the criticism we can exert on the effectiveness of the educational leadership we must take into account both the administrative side off the leadership responsibilities as they raised from both the various definitions we have set for the leadership as well as from the Greek mainly legislation governing the operation of edlucational units and defines clear criteria of effectiveness which are set more as objectives and competences of the educational administration and less as criteria evaluation.

In summary, we can observe that the evaluation and assessment of the effectiveness of the directors of school units has been done both at administrative and teaching level, provided that the relevant legislation makes it clear that the director provides administrative and teaching work. The effectiveness also has to do with meeting objectives both at the administrative level and in the level of development of the human resources of educational units and the formation of climate and attitudes. It is understood from the above that effectiveness is the result of achieving the objectives that are come with appropriate behaviours, particular characteristics of school leaders and their leadership style which is exercised. Maintaining the quality and effectiveness of high-level education, presuppose the existence of commonly accepted control procedures as well as common acceptable criteria for assessing the quality and effectiveness. In other words, when we refer to the concept of effective educational leadership evaluation, we should consider this as a dynamic, complex function, based on foundations, such as the characteristics of the personality of the leader and his team, culture and maturity of the group, 
with a set specific targets and the objectives pursued respectively, in a given time period, with a constructive, objectively and defined process.

\section{Methodology}

\subsection{A Suggestion for a Holistic Educational Leadership Evaluation Model}

Assessing the effectiveness of educational leadership is a process that involves many different stakeholders. When the evaluation relies only to one aspect which the educational leadership affects, then the process is incomplete, unambiguous and controversial because it does not take into account all the addressees and does not consider the implications, effects of leadership on other parties and the respective objectives and targets set by them. In the light of the above, it follows that a model of evaluation of the educational leadership to be fair and effective should be holistic and multifaceted, i.e. to include to the fullest extent possible, all interested parties and recipients that the educational leadership influences and from each interested side to set specific quantitative and qualitative criteria for the effectiveness of the educational leadership, concerning the respective recipient and bring about significant results to each of them. Since the recipients of the educational leadership are many and different from each other, it will therefore be different as well as the criteria of effectiveness of the educational leadership for each of them according to the respective objectives that will put. Such an evaluation model will be much more effective, objective, meritocratic, multi-faceted integrated and functional, as it will include the crisis concurrently of many different sides, will highlight specific weaknesses and shortcomings of leadership on focused issues and will limit biased criticism due to its multi-shareholding assessment. At the same time it will operate in a restrictive form, in any outside of the educational environment possible intervention effort, due precisely to the multitude and diversity of the parties and evaluation members which are actively involved.

The evaluation of effectiveness in educational leadership is a function of the general initial direction of a specific objective and subsequent to the individual criteria of this objective-direction.

More specifically, a first goal in a specific direction of educational leadership can be, for example, students, student community. In this direction the individual objectives and therefore criteria of the performance or effectiveness of the educational leadership may be the performance of pupils in the various courses and final exams, the development of specific skills, such as analytical, synthetic, critical thinking and ability, knowledge acquisition, development of right attitudes and the shaping of a culture.

A second goal in another direction of educational leadership can be, for example, parents and the general school community. In this direction the individual objectives and criteria of the performance or effectiveness of the educational leadership can be the development of relations with the local community and the institutions, the association of parents, networking and synergies with other schools, creation of a climate of cooperation, the vision of the school, the strengthening of relations and cooperation with the parents of pupils, the formation of a suitable school climate, engagement in extracurricular activities, the networking of the school with other interested schools or groups such as the structures of the local community, professional bodies, organizations. 
A third goal in another direction of educational leadership can be, for example, the educational and administrative community i.e. teachers and administrative personnel. In this direction, the individual objectives and criteria of the performance or effectiveness of the educational leadership can be the development of teachers' skills, the creation and cultivation of correct attitudes and behaviours, their empowerment, the extent to which both academics and administrative personnel are satisfied by their work, the degree of satisfaction from the way the leadership is exercised, the strengthening of their knowledge, the improvement of their efficiency, the reinforcement of teamwork and cooperation between them, the increased participation of them in taking decisions according to the leadership style applied, the attainment of the pedagogical and operational goals respectively.

A fourth goal in another direction of educational leadership can be the implementation of the current, regulated education policy of the Ministry and the country. In this direction the individual objectives and criteria of the performance or effectiveness of the educational leadership can be the unhindered functional organizational structure of the school, the application of the existing educational legislation with the minimum possible deviations from this, the fulfilment of the organisational and other objectives set, the observance of procedures, planning, organisation, coordination and operation of the school within the financial budget, the limitation and elimination of any form of delinquency.

\section{Designing the Evaluation Model of Educational Leadership Effectiveness}

The proposed model should include clear objectives and corresponding criteria for evaluating the effectiveness of the educational leadership (EKPIS, Educational Key Performance Indicators \& Standards) depending on the particular educational level and the specific needs of this respectively. Besides according to USA National Policy Board for Educational Administration (2015), which is a consortium of professional organizations committed to advancing school leadership, educational leaders duties and actions involve relentlessly develop and support teachers, create positive working conditions, effectively allocate resources, construct appropriate organizational policies and systems, and engage in other deep and meaningful work outside of the classroom that has a powerful impact on what happens inside it. This work requires educational leaders to build and strengthen a network of organizational supports - the professional capacity of teachers and staff, the professional community in which they learn and work, family and community engagement, and effective, efficient management and operations of the school. Thus given this growing knowledge and the changing demands of the job, educational leaders need new standards to guide their practice in directions that will be the most productive and beneficial to students.

The evaluation model can also be flexible and adjustable, enabling it to regulate and formulate weightiness factors in each individual direction or group of criteria. According to the above, a holistic model of evaluation of educational leadership will be able to include as evaluators, the educational community i.e. teachers and or professors, administrative staff, the student community i.e. students or pupils depending on the educational level, the local school community i.e. parents, association of parents, and the structure of the Ministry of Education with internal or external evaluators. Besides, according to $\operatorname{OECD}(2011, \mathrm{p}$. 14). Greece is one of only a few countries in Europe without external assessment of learning or external evaluation of schools and teaching or indeed any other comparative mechanism of quality 
assurance except for its participation in PISA and university entrance examinations. However, despite the fact that the process of school self-evaluation was frozen in 2015, there is a consensus in Greece that it should be re-introduced, as it could be a good practice, but also because it is believed that can help to lead to a change of attitudes towards evaluation and assessment (IEP, 2016). The availability of better data on student learning outcomes, alongside consensus on national standards for different educational levels, as well as a school quality and outcomes framework for all schools, should help to facilitate reintroduction. Therefore, the evaluation model, should also include the educational leader itself, as an assessor in as self-assessment process, and also include an external, certified, independent evaluation body. The proposed rating agencies are reflected in the Figure 1 below.

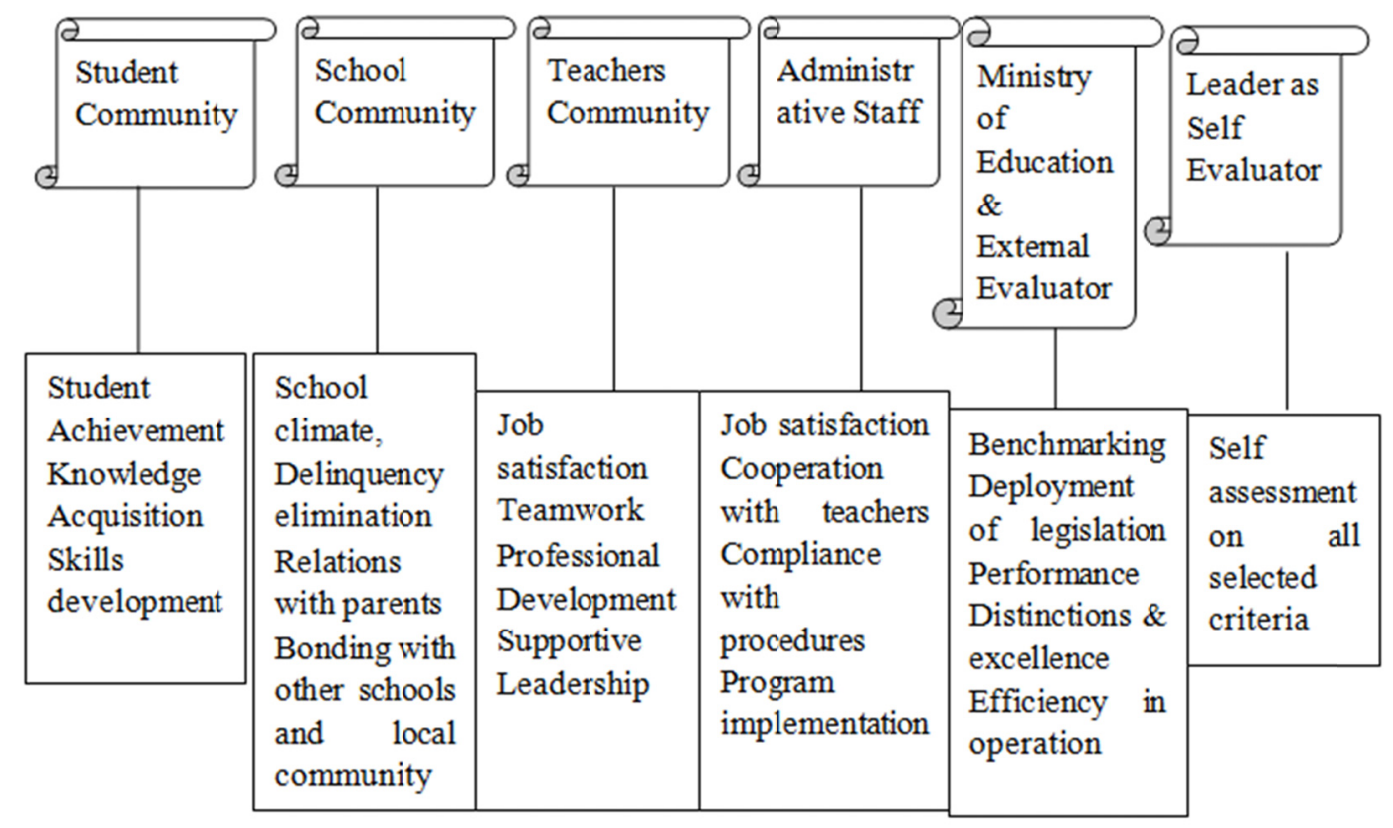

Figure 1. The evaluation model

According to the above mentioned, the proposed evaluation model was designed basically in the findings and suggestions of (OECD, 2011; OECD 2017; IEP, 2016; WORLD BANK, 2017; National Policy Board for Educational Administration, 2015). According to these studies an evaluation framework should take into account the total share holders of educational leadership and may include an external evaluator. Thus, the model has formulated with specific measures of effectiveness using relative criteria for each stake holder as well for the educational leader. The suggested model is complemented additionally with relative specific questionnaire, which have been selected from the department of quality assurance of Malta Ministry of Education, and has three evaluation parts for teachers, students and parents respectively. The aim is throughout this specific questionnaire each stake holder as a recipient of educational leadership to be able to assess educational leadership based on its own relative significant criteria. Concurrently this questionnaire can be used and work as self-evaluation tool for the educational leader, provided that the same content is adapted to the leader as self-evaluator. Thus, when teachers, students, parents, or ministry asses the educational leadership 


\section{Macrothink

effectiveness towards particular objectives and certain criteria-standards, then it comes easy, accurate and fair the educational leaders to evaluate themselves against the same exactly criteria. Therefore, the comparison will be objectively, accountable, comparable and measurable, showing the relative deviations among the ratters, disagreements among them and the issues to be addressed, handled and which need improvement.

The evaluation model with the indicative criteria is reflected in the Table 1 below. In this model there is also the provision for the different weighting of each criterion on the basis of the importance that each interested party attaches to the criterion of effectiveness that it raises against the objective that serves this criterion. In other words, each assessment criterion will have a specific weighting factor to be counted in the overall outcome of the evaluation. Also, in each different educational tier, the criteria for evaluating the effectiveness of the educational leadership may be to a certain extent common, but in some cases should be different as will represent respectively the relevant general and specific objectives of this tier. For example, the objectives and therefore the criteria for evaluating the educational leadership effectiveness between primary, secondary and higher education should be some common as it is school climate and some different as it is the different expected educational outcomes-effects in terms of job market absorption between pupils and graduates respectively.

The evaluation method may be annual and shall take advantage of a structured questionnaire specially designed for each interested side and for each educational tier, and should contain clear measurable quantitative and qualitative performance objectives and criteria with adequately defined reports and examples for each one. The criteria for assessing effectiveness will be specific to each educational tier and each interested side, according to the particular objectives and goals that the educational leadership should achieve for them. Summarizing the proposed model of evaluation of the effectiveness of the educational leadership can include up to six total evaluators a) the academic, teachers and administrative staff, b) the pupil, student community, c) the enlarged school community, d) the state through the Ministry of Education, e) The educational leadership itself with the self-assessment process and f) an external certified independent body evaluator (Table 1). 
Table 1. A holistic educational leadership evaluation model

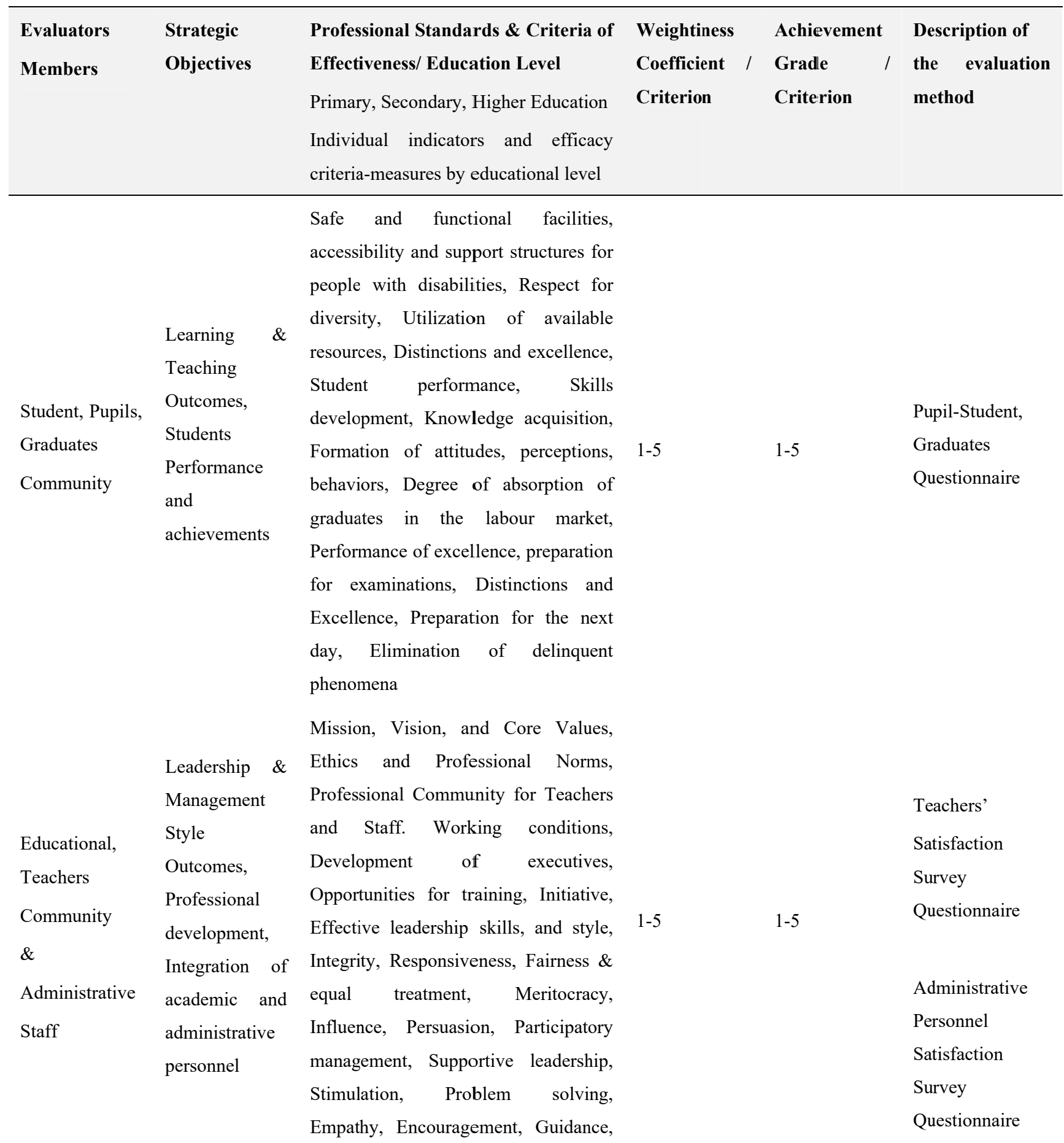

Teamwork \& collaboration 


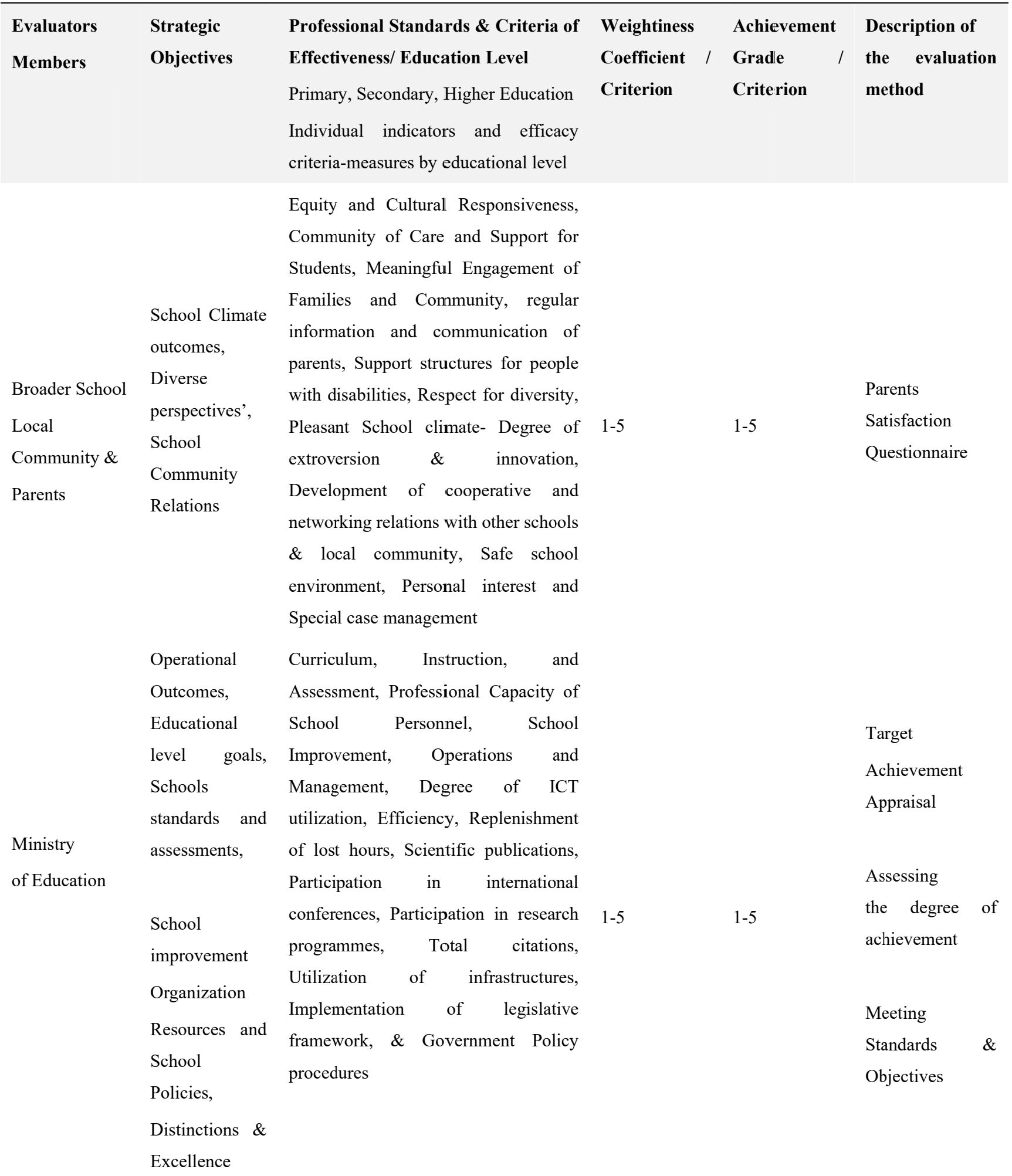




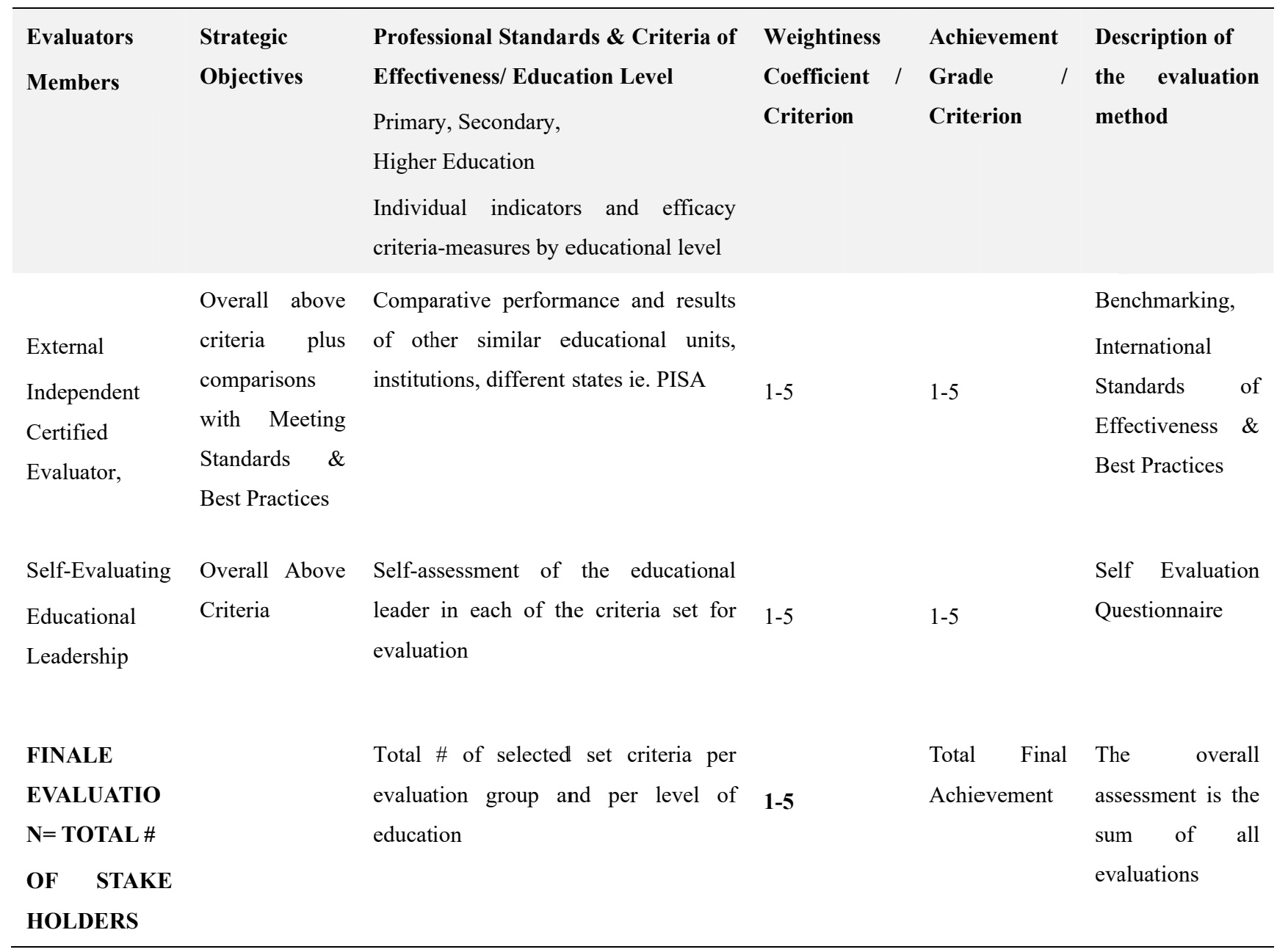

Total evaluation $=$ Sum of $\#$ selected criteria $X$ 1-5 (weightiness factor) X 1-5 (grade achievement).

Each group of evaluators side, selects the most representative criteria for this, gives each of them a weighting factor of $1=$ minimum, up to 5 = maximum weight, depending on the significance of this criterion for that group, and assesses the degree of achievement for each criterion on a Likert Scale from $1=$ zero achievement, up to $5=$ maximum achievement. The overall performance and degree of evaluation effectiveness of the educational leadership results from the partial sum of the degree which attributed to each of the criteria adopted multiplied by the relevant weighting of that criterion. Besides, according to another study on the importance of managerial capacities of school leaders in leading school effectively, interaction between teachers, pupils, parents and local government is valued as crucial in order to institute any educational reform and also students' success is linked with the effectiveness of leadership skills, which also impact the self-efficacy of teachers. Furthermore, school environment and quality of learning, according to their research, influences students' wellbeing (Gjoshi \& Kume, 2014).

\section{Conclusions}

The effectiveness of leadership in the education sector is an issue that increasingly engages the community of educators, researchers, parents, students, education in general, and many studies 
have been done on the issue of its effect on the various addressees of this (McCarty et al., 2014; Aydin et al., 2013; Thompson 2017; Allen, Grigsby and Peters, 2015). This work has attempted to contribute to the commentary and meanings of the concepts of school leadership and its' effectiveness. Emphasis was placed on the correlation, interaction and integration of relative objective and qualitative criteria of educational leadership effectiveness in a functional model which entails all the major stake holders' interests.

With regard to the research questions and more specifically to the first question, is understood and arises through the quotation of the relevant literature that the most appropriate evaluators of the effectiveness of the educational leadership are the main recipients that this impact and these are the academic and administrative staff off school organization, the students, parents and the educational policy throw the ministry of education.

Regarding the second research question, it is understood and perceived through the quotation of the relevant literature that indeed the outcomes of the educational leadership can be measurable with objective and clear criteria and these can be set by different goals, standards and measures according to the interest of each stake holder

As for the third research question it is understood and documented through the quotation of the relevant literature that the criteria for evaluation can identified with relative accuracy, be credible, put with quantifiable, qualitative and quantitative manner and evaluated objectively and multi-factorial based on the main recipients of the educational leadership.

Regarding the concept of effectiveness of educational leadership, important conclusions have emerged in principle in determining the concept of 'effectiveness' and also in how to measure and assess the effectiveness of leadership with specific criteria, parameters. Eventually, with a more accountable way, the effectiveness of an educational leadership can be interpreted and judged objectively on the basis of the results produced as compared to the objectives, criteria and targets which are initially have been set. The criterion here is the degree of achievement of the objectives. At this point it is understood that the objectives are not always the same, in fact they can be many, different, quantitative and qualitative depending on different interests of different recipients.

\subsection{Policy Recommendations and Research Contribution}

According to OECD a key element of an evaluation system, which is now missing in Greece, is a means to assess student learning outcomes through a national student assessment. There are challenges in developing an effective student assessment within the evaluation and assessment framework, such as aligning educational standards and student assessment, balancing external assessments and teacher-based assessments of learning, and integrating student-formative assessments based on results and outcomes (more than on input and procedure) in order to improve the provision of education and to promote accountability across the whole education system. Thus, OECD recommends that Greece needs to design a national system of student assessments that can be used, as appropriate, at multiple levels: the individual student, the classroom, the school, the region and the system. A comprehensive system involves multiple components and is a requirement not only for the development of improvement strategies at all levels (teacher, school, administration) but also for measuring the success in achieving the goals of reform and for establishing a regime of accountability. Evaluations and assessments 
are requirements for an equitable regime of accountability, efficient management, effective decentralisation, and for devolution of autonomy to individual schools (OECD, 2011a). Besides a self-evaluation framework for the educational outcomes of each school is an intention off reforms of Greek educational system in which the scheme proposes specific ways for establishing a framework for evaluating educational staff executives. These reforms, attempted for the first time, will contribute to the decentralization of the education system and the pedagogical autonomy of schools (Hellenic Republic, 2018, p. 63).

This study could contribute to Greek authorities for education, such as Institute for Educational Policy (IEP), Ministry of Education, in their efforts for reforms and assist policy makers, teachers, and school leaders in better understanding the existing effectiveness of school leadership and the significant role of an integrated evaluation model in improving leadership outcomes. The suggested integrated evaluation model may help head teachers, educational leaders and administrators, to learn the way that their leadership affects school community results. These are, for example, students' achievement, school climate, learning results, teachers' performance, personnel satisfaction, relations with teachers, administrative staff, parents and overall school operational performance. The proposed model is unique, as it can provide concurrently, clear information regarding leadership effectiveness towards the anticipated targets and standards that have been set relatively, from the different stake holders. Leaders will become aware to cope with the challenges of the time, with regards to improve results, to uplifting and improving school effectiveness, to be competitive and adoptive to the current changes of the times through this contribution. The multiple assessment criteria and different evaluators integrated in the model can establish its transparency, safeguard evaluation fairness, and focus on specific areas for leadership effectiveness improvement, with comparable sufficient standards.

\subsection{Further Research}

Further studies should be carried out in order to finalise the exclusive objectives and the relevant assessment criteria for each interested side of evaluators in order the evaluation model to be as objective and mainly more representative as possible. It is also important a study to be followed on the degree of acceptance of this model for each education tier. Finally, another study should undergo to check the desirability and level of usefulness of adopting this or a similar model, in other words, the same direct recipients as evaluators, should judge the degree of importance of such an evaluation model of the educational leadership. Policy makers should adopt the importance of evaluating the effectiveness of the education system in general and the educational leadership in particular as they have a multi-faceted influence on a large part of society with critical direct and long-term results. Whichever assessment model will be adopted, however this should not deviate from its fundamental objectives, which must be the objectivity, meritocracy, and transparency and through the emergence of weaknessies that will result, should lead to directions and opportunities for the improvement and optimization of educational policy outcomes. 


\section{References}

Allen, N., Grigsby, B., \& Peters, L. (2015). Does leadership matter? Examining the Relationship Among Transformational Leadership, School Climate, and Student Achievement. NCPEA International Journal of Educational Leadership Preparation, 10(2).

Avci, A. (2015). Investigation of transformational and transactional leadership styles of school principals, and evaluation of them in terms of educational administration. Academic Journals, 10(20), 2758-2767. https://doi.org/10.5897/err2015.2483

Ayhan, A., YIlmaz, S., \& Şengül, U. (2013). The Effect of School Principals' Leadership Styles on Teachers' Organizational Commitment and Job Satisfaction. Educational Sciences, Theory \& Practice, 13(2), 806-811.

Beck, L. G., \& Foster, W. (1999). Administration and community: Considering challenges, exploring possibilities. In J. Murphy, \& K. S. Louis, (Eds.), Handbook of Research on Educational Administration (pp. 337-358). San Francisco: Jossey-Bass.

Bird, J., Wang, C., Watson, J., \& Murray, L. (2009). Relationships among principal authentic leadership and teacher trust and engagement levels. Journal of School Leadership, 19(2), 153-171. https://doi.org/10.1177/105268460901900202

Bruggencate, G., Luyten, H., Scheerens, J., \& Sleegers, P. (2012). Modeling the influence of school leaders on student achievement: How can school leaders make a difference? Educational Administration Quarterly, 48(4), 699-732. https://doi.org/10.1177/0013161X11 436272

Catano, N., \& Stronge, J. H. (2006). What Are Principals Expected to Do? Congruence Between Principal Evaluation and Performance Standards. NASSP Bulletin, 90(3), 221-237. https://doi.org/10.1177/0192636506292211

Clifford, M., Menon, R., Gangi, T., Condon, C., \& Hornung, K. (2012). Measuring School Climate for Gauging Principal Performance. A Review of the Validity and Reliability of Publicly Accessible Measures. American Institutes for Research. https://doi.org/10.1037/ e572172012-001

Cohen, J., McCabe, E.M., Michelli, M. N., \& Pickeral, T. (2009). School climate: Research, policy, practice, and teacher education. Teachers College Record, 111(1), 180-213.

Drucker, P. F. (2012). Kendini yönetmek (Çev. İnan, M.). Esaslar: Harvard Business Review'den en kalıcı yönetim fikirleri. İstanbul: Optimist Yayınlar. In Ahmet Avci (2015). Investigation of transformational and transactional leadership styles of school principals, and evaluation of them in terms of educational administration. Educational Research and Reviews, 10(20), 2758-2767. https://doi.org/10.5897/ERR2015.2483

Edmonds, R. (1979). Effective Schools for the Urban Poor. Educational Leadership, 37(1), 15-18, 20-24.

Elmore, R. F. (2002). Bridging the Gap Between Standards and Achievement.

Everard, K. B., \& Morris, G. (1999). Efficient Educational Administration. EAP (Hellenic Open University), Patra (in Greek). 
Gjoshi, R., \& Kume, K. (2014). Research on the administrator professional training and its role in the implementation of educational institutions reforms in Kosovo. Interdisciplinary Journal of Research and Development, 1(1), 26-30.

Hallinger, P., \& Heck, R. (1996). Reassessing the principal's role in school effectiveness: A review of empirical research, 1980-1995. Educational Administration Quarterly, 32(1), 5-44. https://doi.org/10.1177/0013161X96032001002

Hellenic Republic (2018). Greece: A Growth Strategy for the Future.

Henderson, A. T., \& Mapp, K. L. (2002). A new wave of evidence: The impact of school, family, and community connections on student achievement. Austin, TX: Southwest Educational Development Laboratory.

IEP. (Institute of Educational Policy) (2016). Experts' Reports, report prepared by the IEP and academic experts for the OECD review team, March 2016.

Leithwood, K. A., \& Riehl, C. (2003). What we know about successful school leadership. Philadelphia, PA: Laboratory for Student Success, Temple University.

Leithwood, K. (2002). Organizational learning and school improvement. Greenwich, CT: JAI Press.

Leithwood, K., Louis, S., Anderson, S., \& Wahlstrom, K. (2004). How leadership influences student learning: review of research. Minneapolis, MN, Center for Applied Research and Educational Improvement, University of Minnesota.

Lewis, P. S., Goodman, S. H., \& Fandt, P. M. (1995). Management: Challenges in the 21st century. New York, USA: West Publishing.

Macbeath, J. (2001). Self-assessment at school. Utopia and deed. Athens: Ellinika Grammata. Malta Ministry of Education. Quality Assurance.

Marzano, R. J., Waters, T., \& McNulty, B. A. (2005). School Leadership that Works: From Research to Results. Alexandria, VA: Association for Supervision and Curriculum Development.

McCarty, D., Wallin, P., \& Boggan, M. (2014). Shared Leadership Model for 21 st Century Schools: Principal and Counselor Collaborative Leadership. National Forum of Educational Administration and Supervision Journal, 32(4).

Mulford, B. (2003). School Leaders: Changing Roles and Impact on Teacher and School Effectiveness. A Paper Commissioned by the Education and Training Policy Division, OECD, for the Activity: "Attracting, Developing and Retaining Effective Teachers". Paris, April, 2003. https://doi.org/10.1076/lpos.2.2.109.15546

National Policy Board for Educational Administration. (2015). Professional Standards for Educational Leaders 2015. Reston, VA: Author.

OECD. (2017). Education Policy in Greece: A Preliminary Assessment.

OECD. (2008). Improving School Leadership. Directorate For Education Education and Training Policy Division.

OECD. (2011). Education Policy Advice for Greece, Strong Performers and Successful Reformers in Education. OECD Publishing. 


\section{Macrothink}

International Research in Education

ISSN 2327-5499

2020, Vol. 8, No. 1

OECD. (2013). Synergies for Better Learning. An International perspective on evaluation and assessment. OECD reviews of evaluation and assessment in education. https://doi.org/10. 1787/9789264190658-sum-de

Papanaoum, Z. (1995). The school administration. Theoretical analysis and empirical investigation. Thessaloniki: Kyriakides.

Pont, B., Nusche, D., \& Moorman, H. (2008). Improving school leadership: Policy and practice (Vol. 1). Paris: OECD.

Portin, B. S., Knapp, M. S., Dareff, S., Feldman, S., Russell, F. A., Samuelson, C., \& Ling Yeh, T., (2009). Leadership for Learning Improvement in Urban Schools. University of Washington.

Robinson, V., Lloyd, C., \& Rowe, K. (2008). The impact of leadership on student outcomes: An analysis of the differential effects of leadership types. Educational Administration Quarterly, 44(5), 635-674. https://doi.org/10.1177/0013161X08321509

Saïti, A., (2008). Educational evaluation. National and Kapodistrian University of Athens-ASPETE.

Schoderbek, P. P., Cosier, R. A., \& Aplin, J. C. (1988). Management. San Diego, USA: Harcourt Brace Jovanovich Publishers.

Stravakou, P. (2003). The director of the Primary school unit as its operating force-an empirical research. Thessaloniki: Kyriakidi Brothers.

The Commonwealth Secretariat Report. (1993). Education Programme, Human Resource Development Group Marlborough House Pall Mall, London.

The World Bank. (2017). Education Global Practice. Building Capacity of School Leaders Strategies that Work.

Thompson, Canute Sylvester Dr. (2017). Teachers' Expectations of Educational Leaders' Leadership Approach and Perspectives on the Principalship: Identifying Critical Leadership Paradigms for the 21st Century. Journal of Organizational \& Educational Leadership, 2(2).

Verdis, A. (2002). School Effectiveness and Educational Evaluation in Greece. $\mathrm{PhD}$ thesis at the University of London, Institute of Education, United Kingdom

\section{Glossary}

IEP Institute of Educational Policy

PD Presidential Degree

OECD Organization for Economic Cooperation and Development

EKPIS Educational Key Performance Indicators and Standards 


\section{Macrothink}

\section{Appendix}

Appendix 1. Evaluation Questionnaire

https:/education.gov.mt/en/education/quality-assurance/Documents/QAD\%20SCHOOL\%20I MPROVEMENT/3.\%20Appendices\%20-\%20questionnaires.docx

Appendix I. Teacher Questionnaire

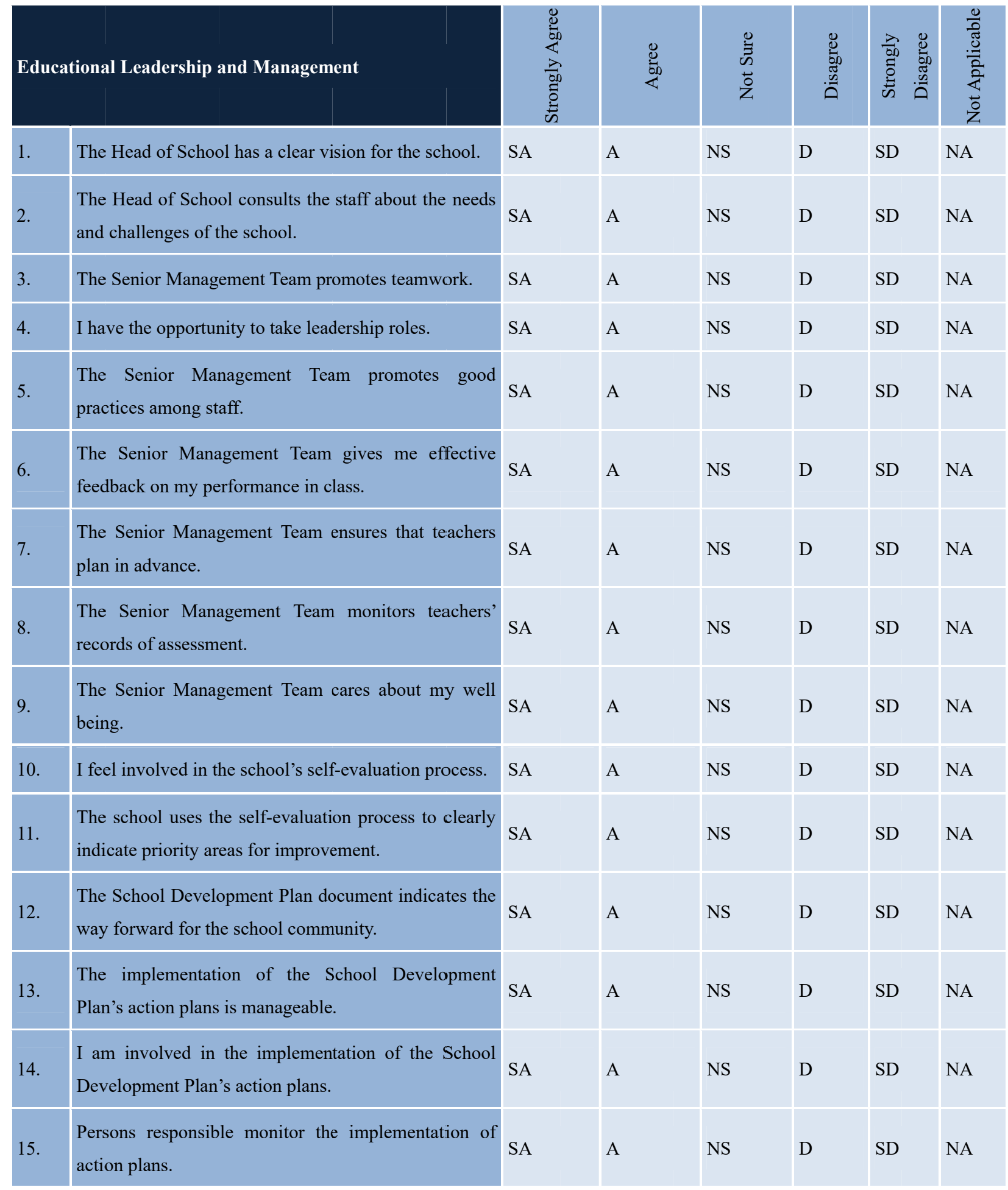




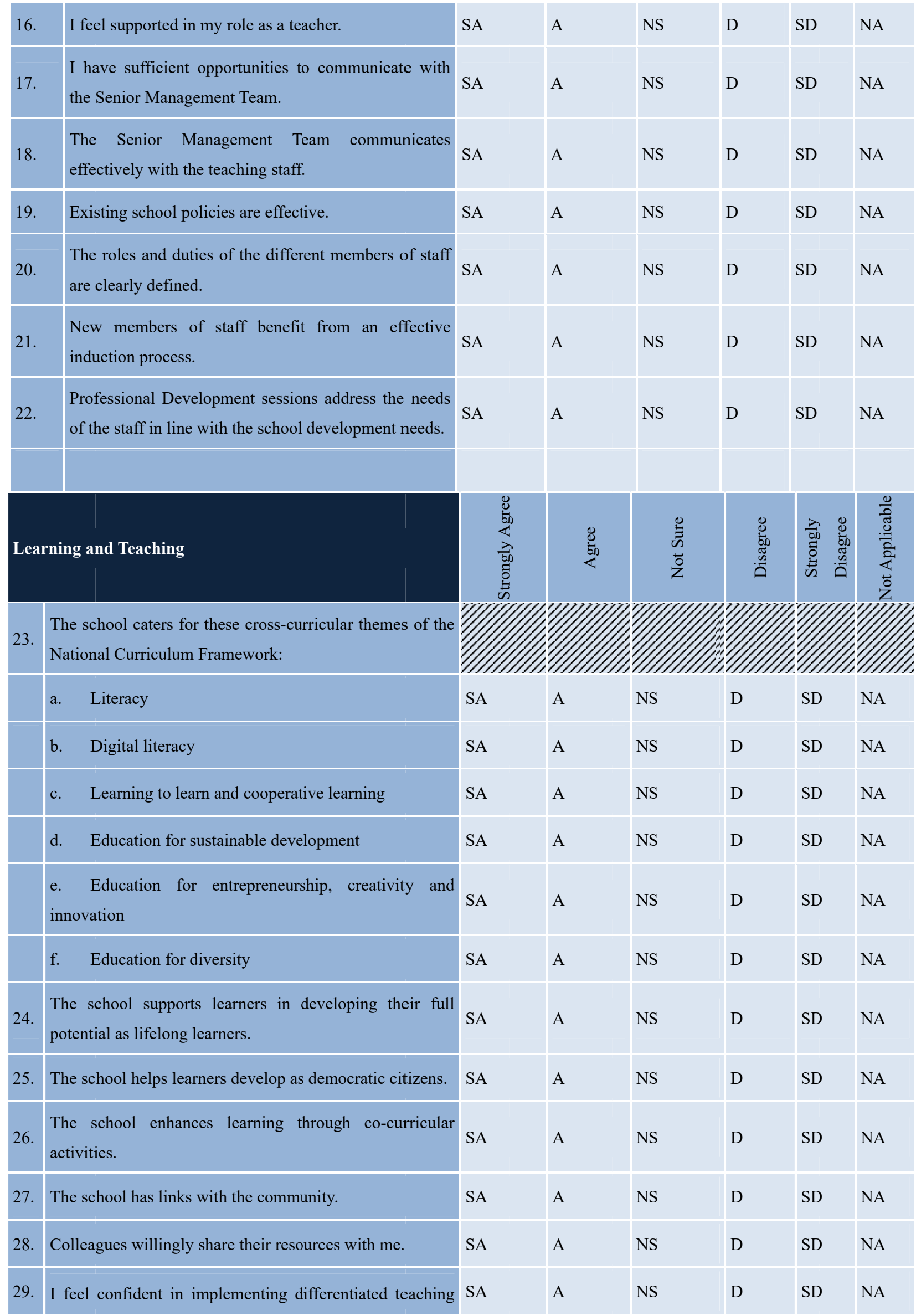




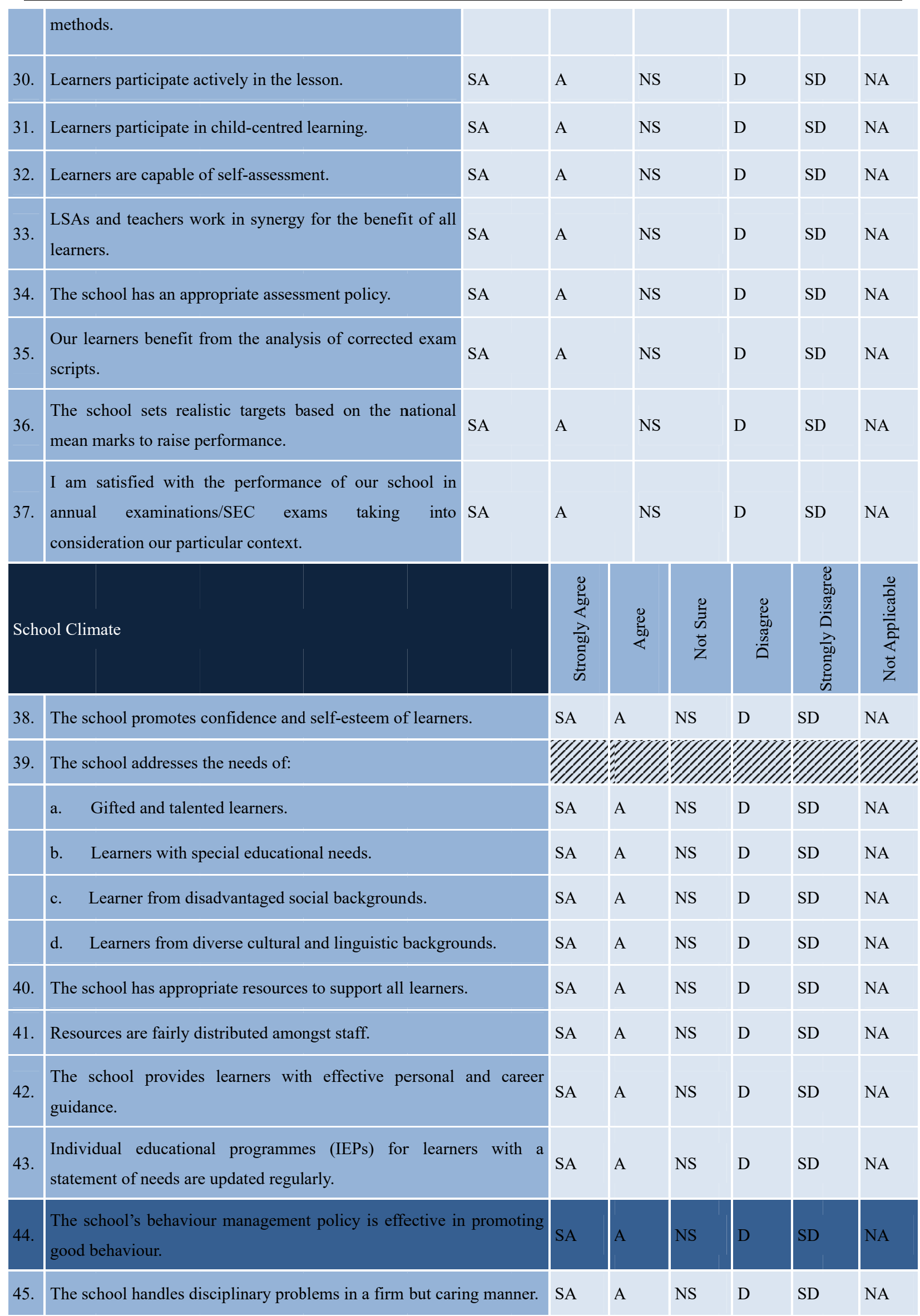




\begin{tabular}{|c|c|c|c|c|c|c|c|}
\hline 46. & The school deals with cases of bullying immediately and effectively. & SA & A & NS & $\mathrm{D}$ & $\mathrm{SD}$ & NA \\
\hline 47. & I feel valued at school. & SA & A & NS & $\mathrm{D}$ & SD & NA \\
\hline 48. & I am satisfied with the school's efforts to tackle absenteeism. & SA & A & NS & $\mathrm{D}$ & SD & NA \\
\hline 49. & The staff supports school initiatives. & SA & A & NS & $\mathrm{D}$ & SD & NA \\
\hline 50. & I feel supported by my colleagues. & SA & A & NS & $\mathrm{D}$ & SD & NA \\
\hline 51. & Learners participate actively in school organised activities. & SA & A & NS & $\mathrm{D}$ & $\mathrm{SD}$ & NA \\
\hline 52. & The school fosters mutual respect among staff members. & SA & A & NS & $\mathrm{D}$ & $\mathrm{SD}$ & NA \\
\hline 53. & The school fosters mutual respect among learners. & SA & A & NS & $\mathrm{D}$ & $\mathrm{SD}$ & NA \\
\hline 54. & Parents regularly follow their child's educational progress. & SA & A & NS & $\mathrm{D}$ & $\mathrm{SD}$ & NA \\
\hline 55. & Parents readily cooperate with the school. & SA & A & NS & $\mathrm{D}$ & $\mathrm{SD}$ & NA \\
\hline 56. & Parents attend parents' day. & SA & A & NS & $\mathrm{D}$ & SD & NA \\
\hline 57. & Parents participate in activities organised by the school. & SA & A & NS & $\mathrm{D}$ & SD & NA \\
\hline 58. & I feel fulfilled working in my school. & SA & A & NS & $\mathrm{D}$ & SD & NA \\
\hline
\end{tabular}

\section{Appendix II. Student Questionnaire}

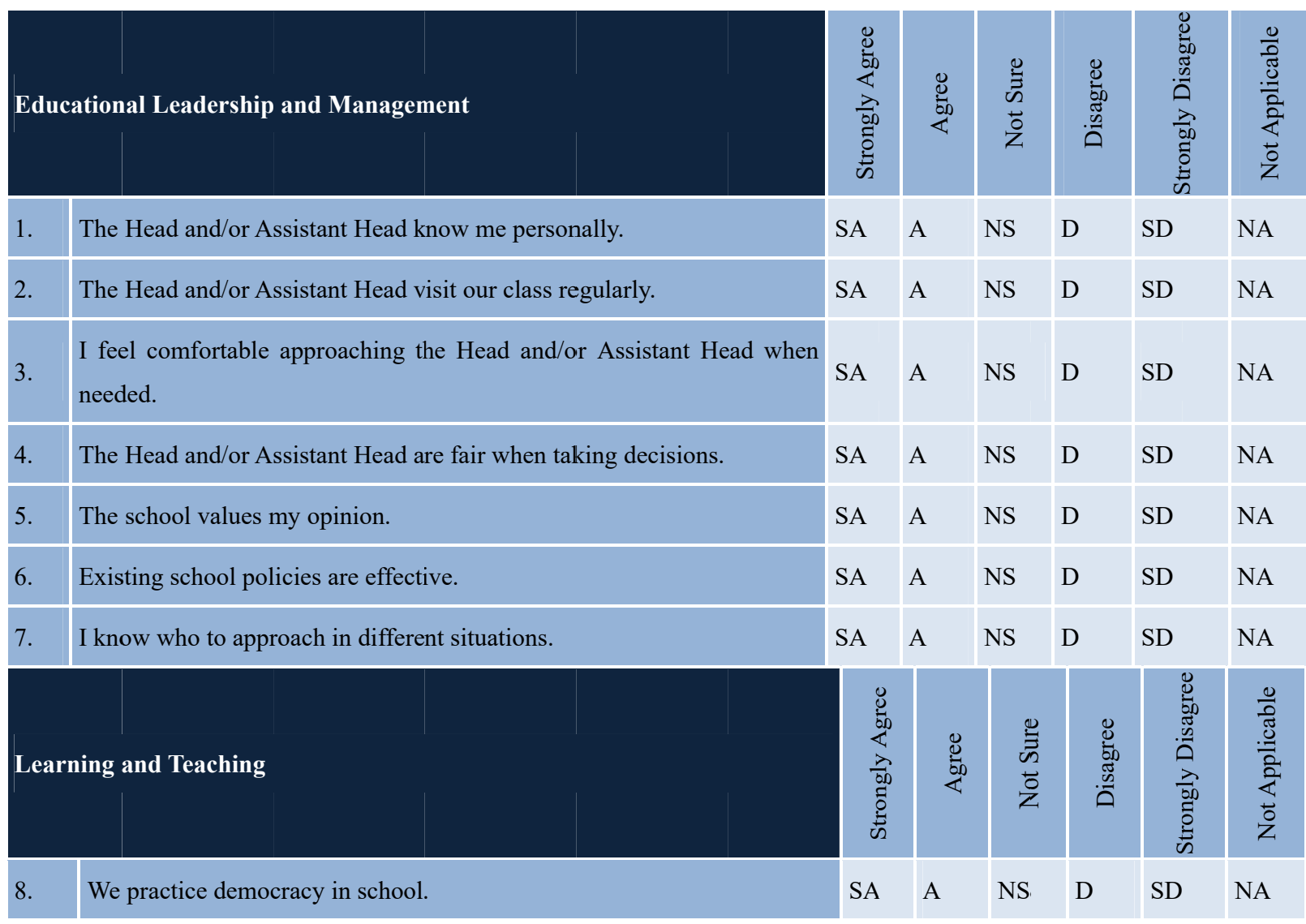




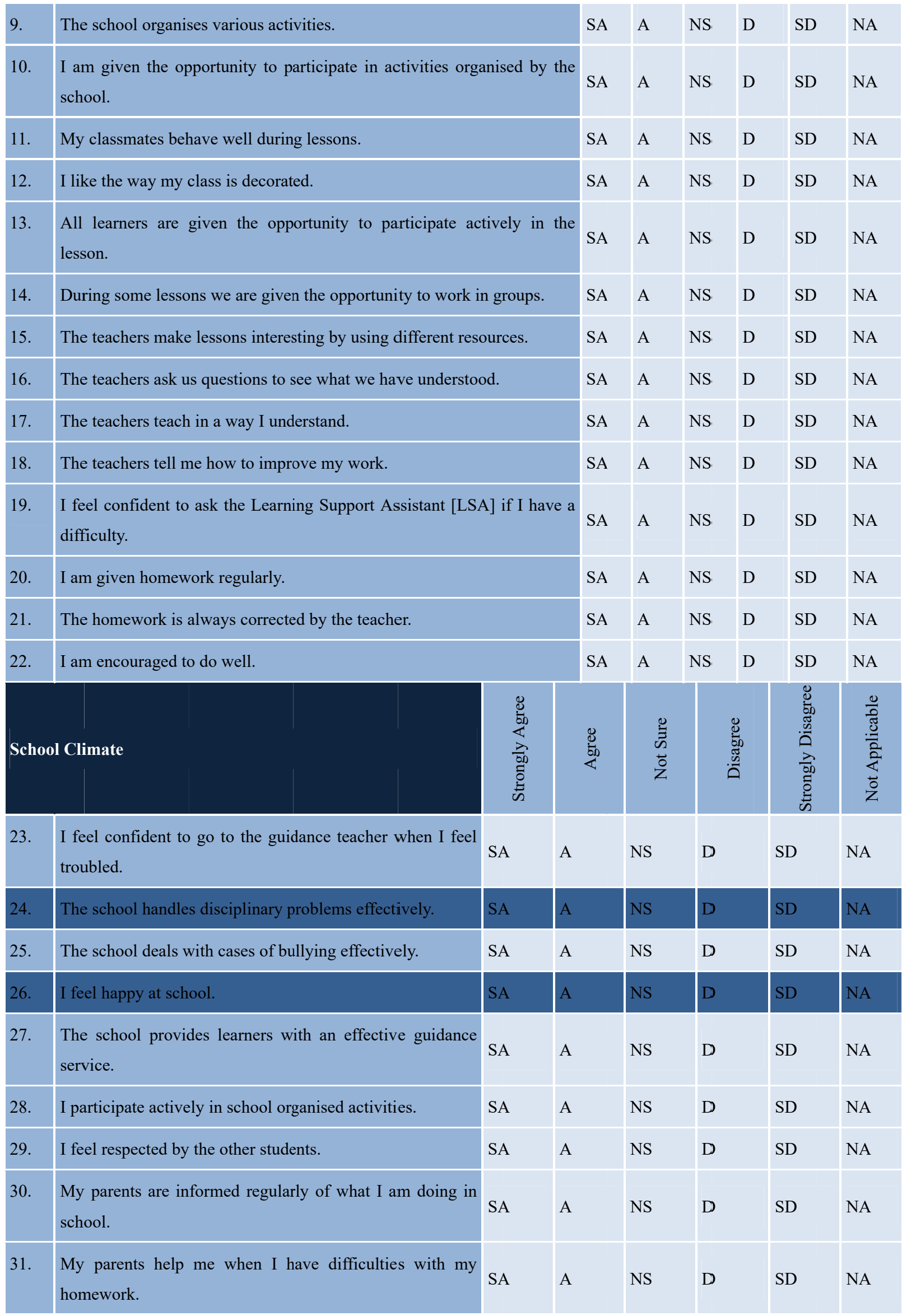


Appendix III. Parent Questionnaire

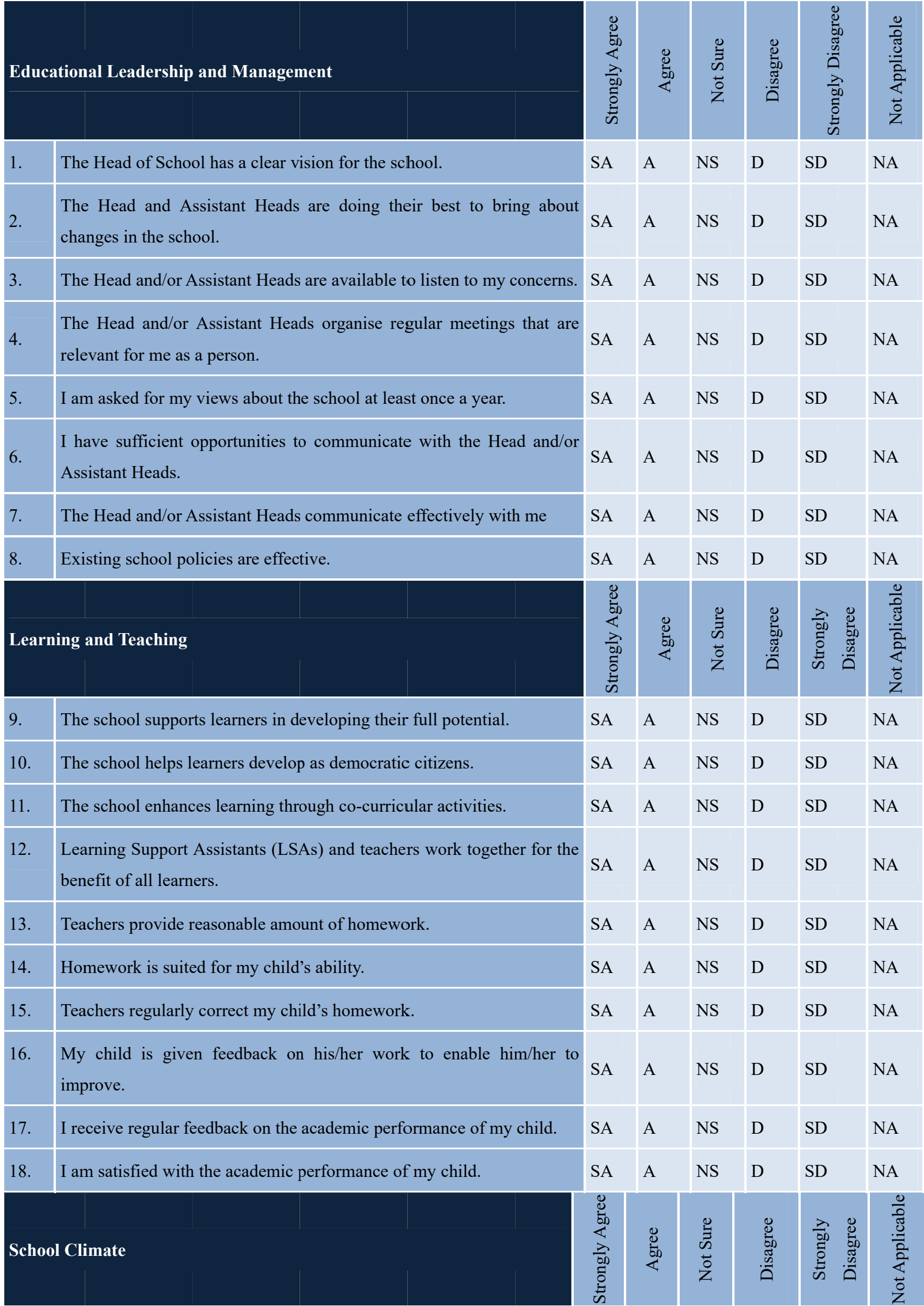




\begin{tabular}{|c|c|c|c|c|c|c|c|}
\hline 19. & The school promotes students' self-esteem. & SA & A & NS & $\mathrm{D}$ & SD & NA \\
\hline \multirow[t]{4}{*}{20.} & The school addresses the needs of: & & & & & & \\
\hline & a. Gifted and talented learners. & SA & A & NS & $\mathrm{D}$ & SD & NA \\
\hline & b. Learners with special educational needs. & SA & A & NS & $\mathrm{D}$ & SD & NA \\
\hline & c. Learners from diverse cultural and/or linguistic backgrounds & SA & A & NS & $\mathrm{D}$ & SD & NA \\
\hline 21. & $\begin{array}{l}\text { The school provides learners with effective personal and career } \\
\text { guidance. }\end{array}$ & SA & A & NS & $\mathrm{D}$ & $\mathrm{SD}$ & NA \\
\hline 22. & $\begin{array}{l}\text { Individual educational programmes (IEPs) for learners with a } \\
\text { statement of needs are updated regularly. }\end{array}$ & SA & A & NS & $\mathrm{D}$ & SD & NA \\
\hline 23. & $\begin{array}{l}\text { The school's behaviour management policy is effective in promoting } \\
\text { good behaviour. }\end{array}$ & SA & A & NS & $\mathrm{D}$ & $\mathrm{SD}$ & NA \\
\hline 24. & The school handles disciplinary problems in a firm but caring manner. & SA & A & NS & D & SD & NA \\
\hline 25. & The school deals with cases of bullying immediately and effectively. & SA & A & NS & $\mathrm{D}$ & SD & NA \\
\hline 26. & The school values parents' contribution. & SA & A & NS & $\mathrm{D}$ & $\mathrm{SD}$ & NA \\
\hline 27. & I am satisfied with the school's efforts to tackle absenteeism. & SA & A & NS & $\mathrm{D}$ & SD & NA \\
\hline 28. & My child participates actively in school organised activities. & SA & A & NS & $\mathrm{D}$ & SD & NA \\
\hline 29. & The school encourages respect among parents & SA & A & NS & $\mathrm{D}$ & SD & NA \\
\hline 30. & I regularly follow my child's educational progress. & SA & A & NS & $\mathrm{D}$ & SD & NA \\
\hline 31. & Parents readily cooperate with the school. & SA & A & NS & D & SD & NA \\
\hline 32. & I regularly attend parents' day. & SA & A & NS & D & SD & NA \\
\hline 33. & I am invited to take part in school events. & SA & A & NS & $\mathrm{D}$ & SD & NA \\
\hline 34. & I regularly take part in school events. & SA & A & NS & $\mathrm{D}$ & $\mathrm{SD}$ & NA \\
\hline 35. & The school addresses problems I raise in a timely manner. & SA & A & NS & $\mathrm{D}$ & SD & NA \\
\hline 36. & I would recommend the school to other parents. & SA & A & NS & $\mathrm{D}$ & $\mathrm{SD}$ & NA \\
\hline
\end{tabular}

\section{Copyright Disclaimer}

Copyright reserved by the authors.

This article is an open-access article distributed under the terms and conditions of the Creative Commons Attribution license (http://creativecommons.org/licenses/by/3.0/). 